\title{
Large-Scale Demonstration Test Plan for Digface Data Acquisition System
}

\author{
L. G. Roybal \\ J. M. Svoboda
}

Published November 1994

Idaho National Engineering Laboratory Lockheed Idaho Technologies Company

Idaho Falls, Idaho $\mathbf{8 3 4 1 5}$ 


\section{DISCLAIMER}

This report was prepared as an account of work sponsored by an agency of the United States Government. Neither the United States Government nor any agency thereof, nor any of their employees, make any warranty, express or implied, or assumes any legal liability or responsibility for the accuracy, completeness, or usefulness of any information, apparatus, product, or process disclosed, or represents that its use would not infringe privately owned rights. Reference herein to any specific commercial product, process, or service by trade name, trademark, manufacturer, or otherwise does not necessarily constitute or imply its endorsement, recommendation, or favoring by the United States Government or any agency thereof. The views and opinions of authors expressed herein do not necessarily state or reflect those of the United States Government or any agency thereof. 


\section{DISCLAIMER}

Portions of this document may be illegible in electronic image products. Images are produced from the best available original document. 


\section{Large-Scale Demonstration Test Plan for Digface Data Acquisition System}

Prepared by
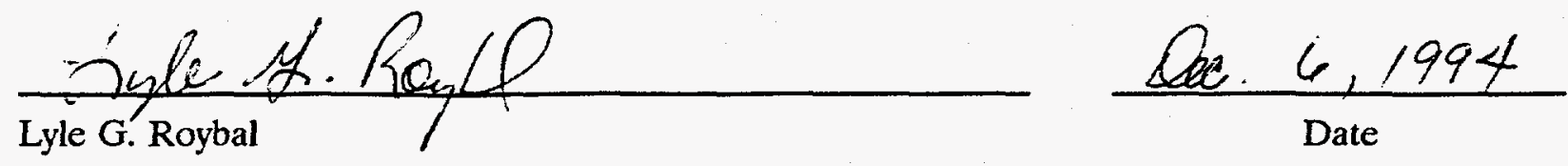

Reviewed by
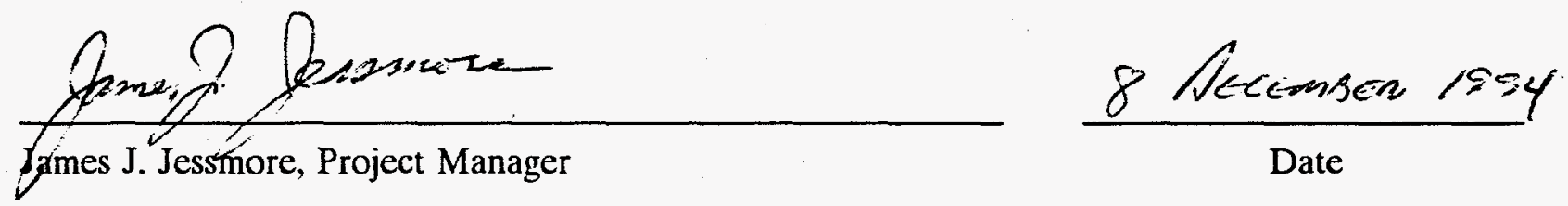

Approved by

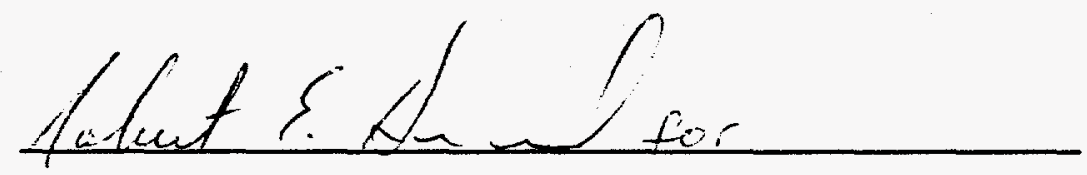

Kevin M. Kostelnik, Buried Waste Integrated Demonstration Program Manager

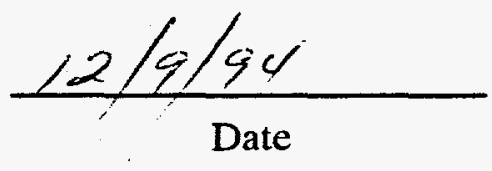




\begin{abstract}
The digface characterization system at the Idaho National Engineering Laboratory was initially demonstrated in FY-93 at the Cold Test Pit. In FY-94, work began in support of a largescale demonstration coordinating the various facets of a prototype digface remediation operation including characterization, contaminant suppression, and cold waste retrieval. This test plan describes the activities that will be performed during the winter of FY-95 that are necessary to assess the performance of the data acquisition and display system in its initial integration with hardware developed in the Cooperative Telerobotic Retrieval (CTR) program. The six specific objectives of the test are determining system electrical noise, establishing a dynamic background signature of the gantry crane and associated equipment, determining the resolution of the overall system by scanning over known objects, reporting the general functionality of the overall data acquisition system, evaluating the laser topographic functionality, and monitoring the temperature control features of the electronic package.
\end{abstract}





\section{SUMMARY}

Digface characterization promotes the use of online site characterization and monitoring during waste retrieval efforts, a need that arises from safety and efficiency considerations during the cleanup of a complex waste site. Information concerning conditions at the active digface can be used by operators as a basis for adjusting retrieval activities to reduce safety risks and to promote an efficient transition between retrieval and downstream operations. Most importantly, workers are given advance warning of upcoming dangerous conditions. In addition, detailed knowledge of digface conditions provides a basis for selecting tools and methods that avoid contamination spread and work stoppages.

The Digface Characterization Project has pursued development of this technology since June 1992 through the support of the Buried Waste Integrated Demonstration (BWID) program. The digface characterization concept was initially demonstrated in FY-93 at the Cold Test Pit located on the Idaho National Engineering Laboratory. In FY-94, work began in support of a large-scale demonstration coordinating the various facets of a prototype digface remediation operation including characterization, contaminant suppression, and cold waste retrieval.

This test plan describes the activities necessary to assess the performance of the data acquisition and display system in its initial integration with hardware developed in the Cooperative Telerobotic Retrieval (CTR) program within BWID. Tests of the data acquisition system (DAS) will be done at the North Boulevard Annex.

A sensor package containing one magnetic gradiometer and associated controlling electronics will be manually mounted onto the mast of digface deployment platform. Objectives for this test series can be classified under determining the general functionality of the system, estimating positional accuracy and digital representation of the potential fields that are measured, and observing the effects of the CTR structure and associated equipment on the measurements and operation of the DAS. These general areas can be focused into six specific objectives that are determining system electrical noise, establishing a dynamic background signature of the gantry crane and associated equipment, determining the resolution of the overall system by scanning over known objects, reporting the general functionality of the overall DAS, evaluating the laser topographic functionality, and monitoring the temperature control features of the electronic package.

This test plan includes the organization and responsibilities of people involved with the project; a description of the test; the sequence of activities; sampling and data techniques; document control; data reduction, validation, and verification; quality assurance; equipment and instruments; supplies, utilities, and facilities; and health and safety. 



\section{CONTENTS}

ABSTRACT $\ldots \ldots \ldots \ldots \ldots \ldots \ldots \ldots \ldots \ldots \ldots \ldots \ldots \ldots \ldots \ldots \ldots \ldots \ldots \ldots \ldots \ldots \ldots \ldots$

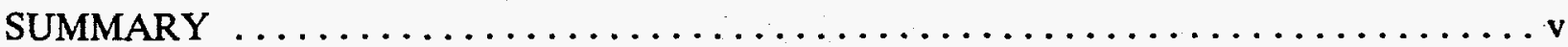

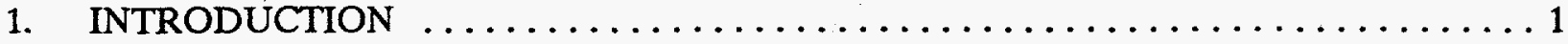

1.1 Technology Description and Background $\ldots \ldots \ldots \ldots \ldots \ldots \ldots \ldots \ldots \ldots$

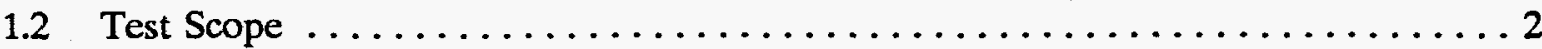

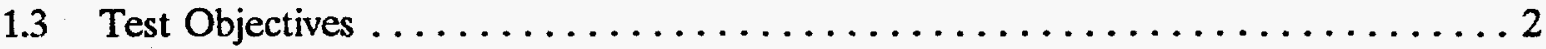

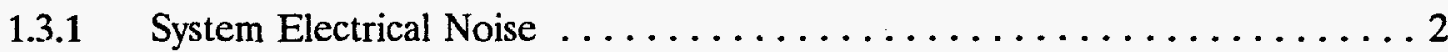

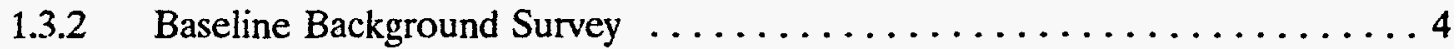

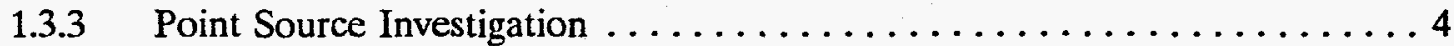

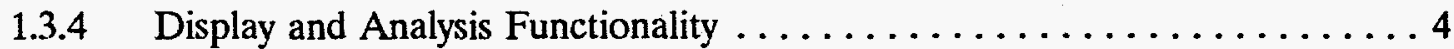

1.3.5 Laser Topographic Functionality $\ldots \ldots \ldots \ldots \ldots \ldots \ldots \ldots \ldots$

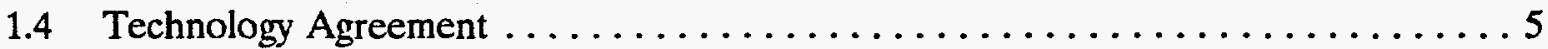

2. ORGANIZATION AND RESPONSIBILITIES $\ldots \ldots \ldots \ldots \ldots \ldots \ldots \ldots \ldots \ldots \ldots$

3. TEST DESCRIPTION $\ldots \ldots \ldots \ldots \ldots \ldots \ldots \ldots \ldots \ldots \ldots \ldots \ldots \ldots \ldots \ldots$

4. SEQUENCE OF ACTIVITIES $\ldots \ldots \ldots \ldots \ldots \ldots \ldots \ldots \ldots \ldots \ldots \ldots$

5. SAMPLING AND DATA $\ldots \ldots \ldots \ldots \ldots \ldots \ldots \ldots \ldots \ldots \ldots \ldots \ldots \ldots \ldots$

5.1 CERCLA Compliance $\ldots \ldots \ldots \ldots \ldots \ldots \ldots \ldots \ldots \ldots \ldots \ldots \ldots \ldots$

6. DOCUMENT CONTROL $\ldots \ldots \ldots \ldots \ldots \ldots \ldots \ldots \ldots \ldots \ldots \ldots \ldots \ldots$

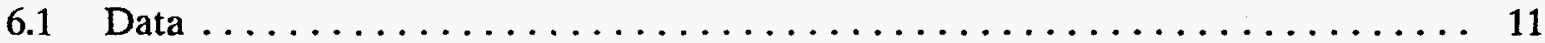

6.2 Test Plan $\ldots \ldots \ldots \ldots \ldots \ldots \ldots \ldots \ldots \ldots \ldots \ldots \ldots \ldots \ldots \ldots \ldots \ldots$

6.3 Reporting and Logbooks $\ldots \ldots \ldots \ldots \ldots \ldots \ldots \ldots \ldots \ldots \ldots \ldots \ldots \ldots \ldots \ldots$

7. ANALYTICAL METHODS $\ldots \ldots \ldots \ldots \ldots \ldots \ldots \ldots \ldots \ldots \ldots \ldots \ldots \ldots \ldots$

8. DATA REDUCTION, VALIDATION, AND VERIFICATION . . . . . . . . 13

8.1 Data Reduction $\ldots \ldots \ldots \ldots \ldots \ldots \ldots \ldots \ldots \ldots \ldots \ldots \ldots \ldots \ldots \ldots$

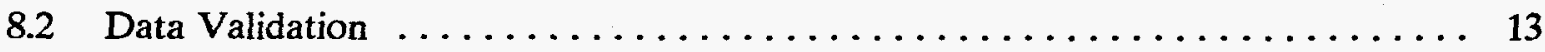


8.3 Acceptance Criteria $\ldots \ldots \ldots \ldots \ldots \ldots \ldots \ldots \ldots \ldots \ldots \ldots \ldots \ldots \ldots \ldots$

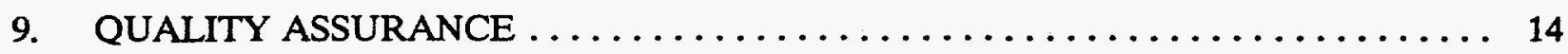

9.1 General Quality Control Methods $\ldots \ldots \ldots \ldots \ldots \ldots \ldots \ldots \ldots \ldots \ldots \ldots$

9.2 Specific Quality Control Procedures $\ldots \ldots \ldots \ldots \ldots \ldots \ldots \ldots \ldots \ldots \ldots$

10. EQUIPMENT AND INSTRUMENTS $\ldots \ldots \ldots \ldots \ldots \ldots \ldots \ldots \ldots \ldots \ldots \ldots$

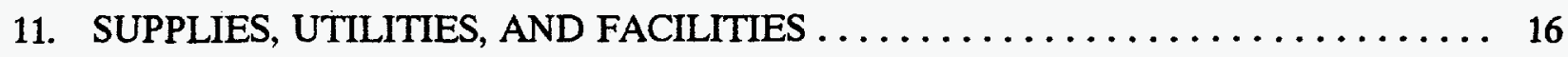

12. HEALTH AND SAFETY $\ldots \ldots \ldots \ldots \ldots \ldots \ldots \ldots \ldots \ldots \ldots \ldots \ldots \ldots \ldots \ldots$

13. RESIDUALS MANAGEMENT $\ldots \ldots \ldots \ldots \ldots \ldots \ldots \ldots \ldots \ldots \ldots \ldots$

14. REFERENCES . . . . . . . . . . . . . . . . . . . . . . 19

Appendix $A-$ Sensor Technical Specifications $\ldots \ldots \ldots \ldots \ldots \ldots \ldots \ldots \ldots \ldots \ldots \ldots$

Appendix B-DAS Drawings and Schematics $\ldots \ldots \ldots \ldots \ldots \ldots \ldots \ldots \ldots \ldots \ldots$ 


\section{Large-Scale Demonstration Test Plan for Digface Data Acquisition Plan}

\section{INTRODUCTION}

Digface characterization promotes the use of online site characterization and monitoring during waste retrieval efforts, a need that arises from safety and efficiency considerations during the cleanup of a complex waste site. Waste retrieval involves initial, uncontrolled contact with unknown and potentially dangerous materials and constitutes one of the greatest safety risks during a remedial program. Waste retrieval also initiates a complex sequence of events that includes assaying, sorting, treating, and disposing of the retrieved waste. These downstream activities strongly influence the speed, cost, and effectiveness of the remediation process.

Information concerning conditions at the active digface can be used by operators as a basis for adjusting retrieval activities to reduce safety risks and to promote an efficient transition between retrieval and downstream operations. Most importantly, workers are given advance warning of upcoming dangerous conditions. In addition, detailed knowledge of digface conditions provides a basis for selecting tools and methods that avoid contamination spread and work stoppages.

The Digface Characterization Project has pursued development of this technology since June 1992 through the support of the Buried Waste Integrated Demonstration (BWID) program. The digface characterization concept was initially demonstrated in FY-93 at the Cold Test Pit at the Idaho National Engineering Laboratory (INEL). The Cold Test Pit contains simulated waste areas designed to imitate waste configurations found in radioactive/hazardous burial areas throughout the Department of Energy complex. In FY-94, work began in support of a large-scale demonstration coordinating the various facets of a prototype digface remediation operation including characterization, contaminant suppression, and cold waste retrieval. This test plan describes the activities necessary to assess the performance of the data acquisition and display system in its initial integration with hardware developed in the Cooperative Telerobotic Retrieval (CTR) program within BWID.

\subsection{Technology Description and Background}

The digface characterization system consists of sensors, data acquisition and analysis software and hardware, and a sensor deployment system. Multiple sensor types are used to interrogate and classify the waste seam for radiological and chemical hazards. These hazards are determined through direct detection of radiation and chemical fields, and by inferred detection using geophysical techniques such as magnetics and electromagnetic induction devices. These sensors are deployed in a systematic and precise manner such that all portions of the waste area are screened for unknown hazards prior to exposure by an excavation process.

The BWID CTR program will demonstrate a full-scale simulated retrieval operation during the summer of FY-95. The deployment system chosen for the full-scale demonstration is a overhead three-axis crane with two six-degree-of-freedom Schilling arms attached to the crane 
mast. The crane will be remotely operated, delivering sensors and digging apparatuses to a simulated waste seam. Characterization of the digface site will be accomplished by an integrated system that acquires and displays sensor data to an operator in a compact and usable manner. This allows the excavation process to be adjusted or modified in real time, dependent upon the hazards defined by the characterization system. The major subsystems of the digface characterization system are shown in Figure 1.

\subsection{Test Scope}

This document specifically addresses objectives and scope associated with the data acquisition and display system acquiring data from a magnetic gradient sensor. Test objectives and scope concerning the performance of the sensor delivery subsystem (i.e., three-axis crane) are provided in the CTR system test plan (reference 1). The performance of the sensor and data acquisition subsystems will be indirectly influenced by the crane performance with respect to ability to deliver a sensor to a desired position, and the accuracy of the measured crane position with respect to actual crane position. These parameters are addressed in the CTR system test plan.

Tests of the data acquisition system (DAS) will be done at the North Boulevard Annex. A sensor package containing one magnetic gradiometer and associated controlling electronics will be manually mounted onto the mast of the overhead crane. Electrical power (standard 120-Vac, 30-A) for the sensor and electronics package will be provided by the CTR system. Data from the sensor package will be transmitted to a UNIX workstation via radio frequency (RF) ethernet link. Hardwire ethernet cabling will be available from the CTR system as a backup system if required. The UNIX workstation will perform the data display and analysis functions using a graphical user interface (GUI) environment.

\subsection{Test Objectives}

Test objectives for this test series can be classified under determining the general functionality of the system, estimating positional accuracy and digital representation of the potential fields that are measured, and observing the effects of the CTR structure and associated equipment on the measurements and operation of the DAS. These general areas represent a qualitative and quantitative evaluation of the DAS. These can be focused into six specific objectives that are determining system electrical noise, establishing a dynamic background signature of the gantry crane and associated equipment, determining the resolution of the overall system by scanning over known objects, reporting the general functionality of the overall DAS, evaluating the laser topographic functionality, and monitoring the temperature control features of the electronic package.

\subsubsection{System Electrical Noise}

Electrical noise in the data acquisition places a fundamental limit on the resolution capability of the digface characterization system. System noise has two components. The first component is related to the overall quality, construction, and soundness of design of the analog-to-digital (AVD) conversion hardware. This component of system noise will be determined by hovering a 


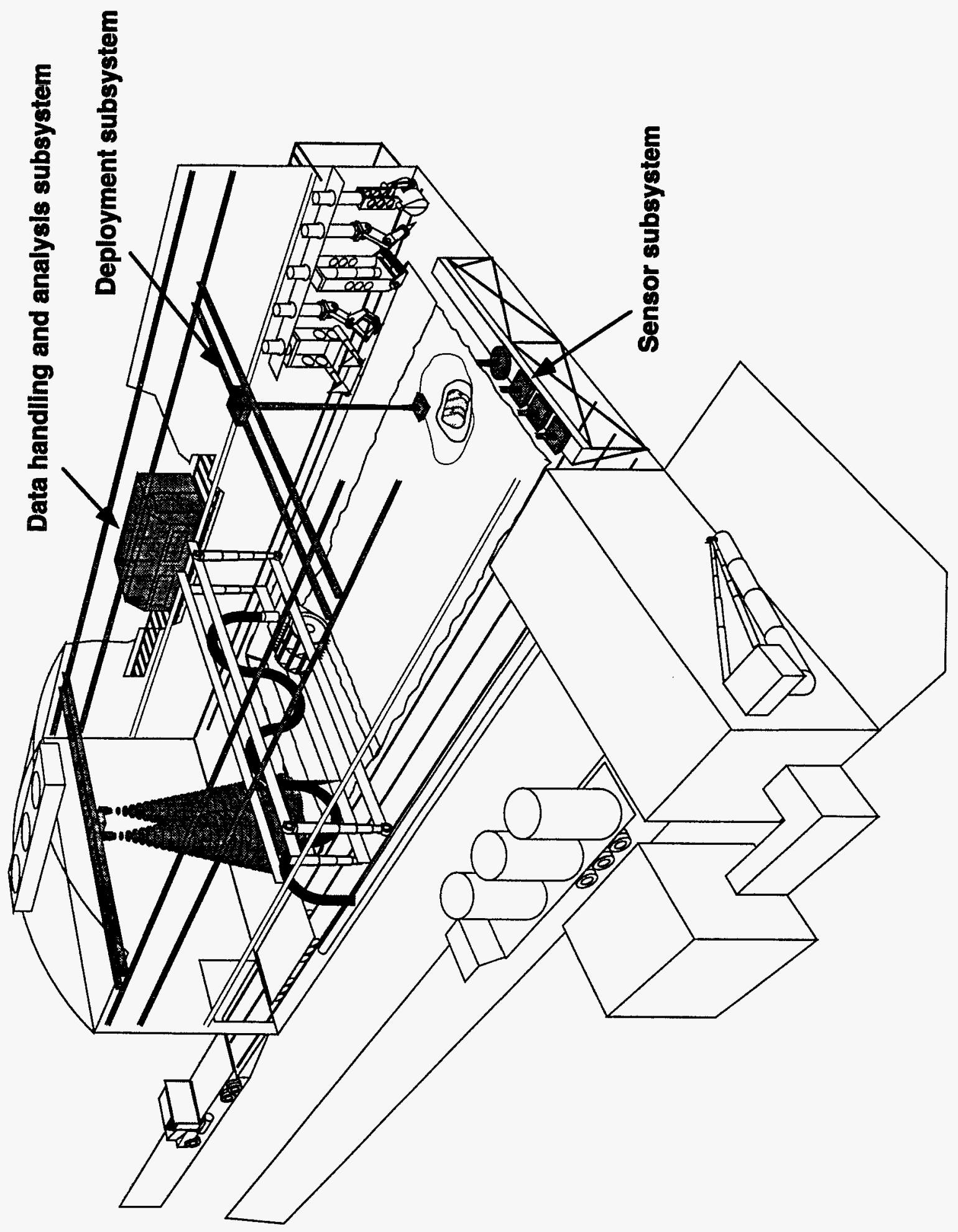

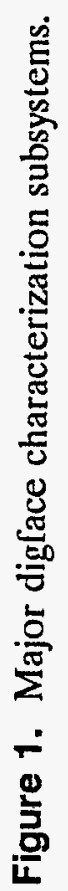


stationary digface system over a minimum of three targets of varying field strength while collecting a minimum of 50 samples. All components associated with the delivery system will be held fixed and de-energized (if possible) so that interference from other non-digface systems will be minimized. This test will be done in two parts. The first part will test the system with known voltage source such that noise in the conversion hardware can be quantified. The second stage will use the magnetic gradiometer to evaluate noise in the magnetic field introduced by the operation of ancillary crane equipment such as motors. A quantitative evaluation of noise in the system will be done by using standard statistical means.

A second set of tests will be conducted to determine the effects of the energized delivery system components on electrical noise. Here, the digface system will be held stationary and various components of the delivery system not associated directly with positioning the digface system will be activated and moved. This includes the second Schilling arm and associated overhead Z-mast, for example. The signal-to-noise ratio will be determined in a similar fashion to the first test sequence.

\subsubsection{Baseline Background Survey}

This test objective will identify the effects of the crane structure on a magnetic survey. This will be done by scanning a small waste and metal free area of approximately $20 \times 30 \mathrm{ft}$ with a magnetic gradiometer. This survey will be repeated five times with the dual objectives of establishing the background effects of a large metallic structure and defining the repeatability of the instrument and DAS in an unstable magnetic background such as that caused by the large moving crane structure.

\subsubsection{Point Source Investigation}

This test objective will identify the spatial accuracy of the DAS/gantry crane delivery system by scanning the area identified in Section 1.3.2 after several small magnetic sources have been placed throughout the survey area. The survey will be conducted at three gantry crane speeds to be determined. Known location of magnetic objects will be compared to survey results. Spatial accuracy will be estimated as a function of speed. Any serious time lags will be identified by this test sequence. Each point source speed test will be repeated three times to augment repeatability measurements taken in Section 1.3.2.

\subsubsection{Display and Analysis Functionality}

This objective will be qualitative in nature and consist of subjective judgments on the overall usability and functionality of the DAS. Any failures of the system will be noted in logbooks in addition to the total "up" time of the system. In this manner a sense of reliability will be established in this limited test series. Also, the overall ergonomic feeling of the DAS will be noted and reported.

\subsubsection{Laser Topographic Functionality}

This test objective will evaluate the reliability and accuracy of the laser topographic capability of the digface sensor suite. This will be scanning a profile over three objects of known 
and varying heights. These objects will be a cardboard box, the shiny side of a coffee can, and a board plank oriented at a 45-degree angle with ground level. Five profiles will be collected over these objects. Accuracy and repeatability will be calculated based on these results.

\subsection{Technology Agreement}

This work is sponsored by BWID as defined in TTP ID 142009. 


\section{ORGANIZATION AND RESPONSIBILITIES}

Primary responsibility for this test series will belong to J. M. Svoboda who is the principal investigator for the data acquisition and display management task of the Digface Characterization Large Scale Demonstration work package. Overall technical coordination and evaluation of the test series will be done by L. G. Roybal. The cost account manager for this work package is J. J. Jessmore of BWID. Figure 2 shows the overall organization for the large-scale demonstration checkout test series.

The data acquisition and display equipment is an extension of the digface sensor delivery system and requires close interaction and communication with CTR personnel. The principal investigator for the sensor delivery system development and deployment is $\mathrm{K}$. M. Croft. In many ways, the success of the system is highly dependent upon the performance of the delivery system. The mechanics for the data acquisition test series will be supervised by Svoboda and coordinated with the CTR test coordinator. This will be Croft or his designee. Svoboda will also be responsible for the evaluation of the DAS from an operative standpoint. This includes items such as correct conversion and archival of sensor signals to engineering units, general reliability of the system, and ease of use. Roybal will be responsible for the evaluating the DAS from operational and environmental perspectives. This includes the effect and interference of the crane structure, motors, and Schilling arms on the sensitivity and resolution of the data sets. Brief descriptions of key technical personnel are provided in Table 1.

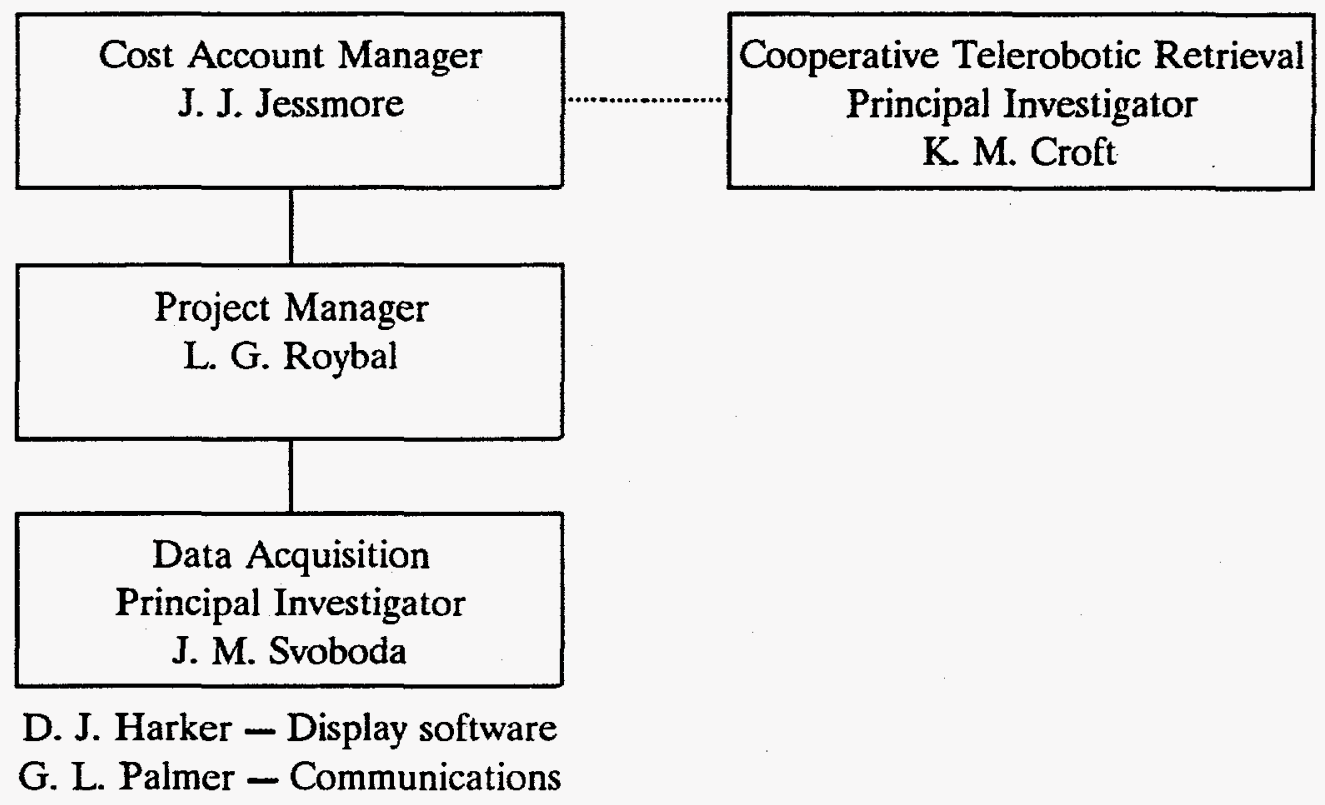

Figure 2. Organizational structure for the large-scale demonstration tests. 
Table 1. Digface characterization system key personnel.

L. G. Roybal Program Manager/Technical Coordinator. Roybal is responsible for coordinating and directing the technical activities required to prepare for the field tests. This includes modifications made to sensors and the DAS.

J. M. Svoboda DAS Technical Leader. Svoboda is responsible for delivering a functional DAS including both hardware and software modifications.

K. M. Croft CTR Principal Investigator. Croft is responsible for directing hardware and software development, and the test series for the overhead crane gantry system. CTR personnel are not directly funded by this work package, but are directly involved with the deployment of the digface characterization system.

Operation of the data acquisition equipment during the test series will be done by data acquisition personnel. No special training requirements are anticipated under normal DAS operations. However, because close coordination with gantry crane personnel is necessary, special training requirements stipulated by the CTR program may be needed. These items are assumed be addressed in the CTR test plan. 


\section{TEST DESCRIPTION}

These initial tests of the digface characterization system will be limited to measurements taken with a magnetic field sensing gradiometer. The fundamental measurement made by the gradiometer is the difference in the Earth's magnetic field in the direction of the sensor axis and between two closely spaced ( 4 in. apart) magnetometers. This is a vector measurement of a three-dimensional geopotential field. The output from the gradiometer is a bipolar analog signal proportional to the field strength aligned with the sensor axis. This signal is converted to digital representation by a 12-bit A/D converter with automated gain control. The conversion factor from analog signal to engineering units is $32,808.4 \mathrm{nT} / \mathrm{m}=1-\mathrm{V}$ output.

The tests will be conducted behind the North Boulevard Annex as part of a large gantry crane test series that will be done by the CTR program. Six separate testing sequences are required to satisfy the objectives established in Section 2 of this test plan. It is anticipated that this will require two days to complete these tests, assuming no major equipment failures are encountered with either the DAS or the delivery system equipment. The schedule will require coordination with the CTR test schedule and necessitate full dedication of the crane operations for two days minimum. Detailed operating procedures for the DAS equipment are provided in Section 4 of this test plan.

Operation of the DAS equipment is through a radio frequency (RF) ethernet link from a Sun workstation to a remote microprocessor for sampling, converting, and transmitting data. All items have been bench tested. However, there is always uncertainty about the performance of prototype equipment when taken from a bench or laboratory operation to a field operation as in this test series. Items of concern include the reliability of the RF link in a field environment, the operation of the microprocessor based remote electronics in a dynamic shock-loaded environment, and the interface between the DAS and the gantry crane for remote, automated position stamping of data. Gantry crane position stamping of data has been simulated in the laboratory. However, this will be the first hardwire connection to this system. A hardwire ethernet connection will be available as a backup position should the RF link not operate reliably.

The conduct of the tests will generally follow that described in Section 4 for each test objective described in Section 2 of this test plan. A copy of the test plan will be maintained in the field. Any major deviation from these procedures will require the approval of the program manager and will be noted as a change control for the test plan. The redline method with authorizing parties initials will be sufficient for change control. Logbooks will be maintained to record of the test sequence. 


\section{SEQUENCE OF ACTIVITIES}

The typical startup and operating sequence for the digface DAS is listed below.

1. Mount the sensor/computer canister on the Schilling arm and connect the $120 \mathrm{Vac}$ power. The system will initialize and wait for commands from the Sun workstation.

2. Power up the Sun workstation (if it is not already booted) and log in using "digface" as the user ID. PV-wave and the digface application will start automatically, with the digface main menu being displayed.

3. Press the "Alarm Setup" button and use the alarm setup window to adjust alarms and other system thresholds. Close the alarm setup window when finished.

4. Press the "Magnetometer" button to display the magnetometer data acquisition screen. Set up the data file and remote $\mathrm{PC}$ executable file, along with the minimum and maximum $X$ and $Y$ distances that define the digface scan boundaries (the $X$ and $Y$ will be obtained from the Silicon Graphics computer if they are readily available).

5. Have the crane operator move the sensor canister to the position at which the laser is to be zeroed.

6. Press the "Initialize Sensors" button to zero the laser.

7. When the "Start Acquisition" button is active, the system is ready to take data. As soon as the crane is ready to scan, press "Start Acquisition" and data acquisition will begin. The data will be displayed on the Sun workstation as it is acquired.

8. Press the "Stop Acquisition" button when the scan is completed. This will make any final updates to the data file and clear out the data file name on the magnetometer screen. The system will require a new file name to be entered before starting another scan. After a filename has been entered, a new scan can be started by pressing the "Start Acquisition" button. The laser can be rezeroed at any time by moving the crane to the "zeroing" position and pressing the "Initialize Sensors" button.

9. View any of the previously acquired datasets by pressing the "Display Data" button on the main menu. The display data screen provides the operator with basic plotting and printing capabilities. The data display functions may be used concurrently with data acquisition.

10. Copy the day's datasets to floppies or 1/4-in. tape at the end of each day. When the archiving is complete, exit the window system and log off the workstation. 


\section{SAMPLING AND DATA}

The digface DAS provides automated data collection and archival functions. Startup parameters are provided by the DAS operator at the Sun workstation and transmitted by RF ethernet link to the digface sensor electronics. The data collection rate is time based and adjustable by the DAS operator. Prior to data collection, system clocks will be synchronized between the Sun workstation, the digface sensor electronics, and the gantry crane controlling computer. Sensor data from the digface will be time stamped and transmitted to the Sun workstation and merged with time-stamped positional data obtained from the gantry crane controller. The data will be archived onto disk in ASCII format with sensor data in engineering units preceded by three-dimensional position data in feet. A number of analysis functions can then be applied to the data as required including gridding, contouring, and plotting.

\subsection{CERCLA Compliance}

This is test series of prototype equipment over an area without environmental wastes or hazards. Therefore, the nine Comprehensive Environmental Response, Compensation, and Liability Act (CERCLA) criteria identified in Table 2 of the BWID Demonstration Technology Test Plan Guidance (EGG-WTD-9800) do not specifically apply to this activity but may apply to future full-scale operations involving this equipment or derivatives of this equipment. 


\section{DOCUMENT CONTROL}

The DAS has been specifically designed to automate much of the data collection and formatting. The DAS acquires and converts raw sensor output (i.e., voltages) to digital values in appropriate units, places a position stamp on the data, and writes the result to permanent storage in the appropriate format for later data processing and image generation.

\subsection{Data}

The data will be incrementally archived onto floppy diskettes each day. This data will be transported and stored at the Research Office Building (ROB) in Idaho Falls. Once testing is complete, a copy of all data and logbooks will be delivered to BWID upon request.

\subsection{Test Plan}

Major changes to this test plan can be made prior to the field work, subject to approval by the BWID project manager. These changes will be in writing and attached to the front of the original test plan with the required approval signatures. A designated master copy containing the original test plan and all subsequent revisions will be located in the field with the test apparatus. The principal investigator or a designated alternate may modify the test plan to account for unanticipated conditions that might occur during the experiments. These changes will be documented by striking out and adding the appropriate text to the master copy of the test plan. All such changes to the test plan will be reported to the BWID project manager at the end of the day.

\subsection{Reporting and Logbooks}

Applied Geotechnologies has established a project file that contains a chronology of all official documentation (i.e., interoffice correspondence, purchase orders) associated with the Digface Characterization Project. A master field logbook will be kept by the principal investigator (or designated alternate) and conform to the practices described in the Applied Geotechnologies Land Magnetic Surveys Standard Operating Procedures. Copies of all data and logbooks will be delivered to BWID upon request. 
Not applicable.

\section{ANALYTICAL METHODS}




\section{DATA REDUCTION, VALIDATION, AND VERIFICATION}

\subsection{Data Reduction}

Most data reduction for this effort will be done automatically by the computer-based DAS. This involves conversion of raw sensor output (volts) to a digital value in the appropriate engineering units. Analog output ranges and conversion factors for the sensors to be used in the performance testing are listed in Table 2. Detailed information on these sensors has been compiled into Appendix A.

\subsection{Data Validation}

All data for these initial checkout tests will be considered valid and used as diagnosis tools to correct deficiencies in the DAS or operating procedures. The magnetic sensor deployed for this test series is factory calibrated and cannot be recalibrated in a field environment. Data will be analyzed for proper position stamping, repeatability, and noise components from both electrical and environmental (i.e., massive steel structures) noise sources. In addition, DAS archival functions will be examined for proper formatting and storage of data. Visual inspection of the data will be done by the principal investigator and/or Applied Geotechnologies personnel to ensure proper function of the sensor.

\subsection{Acceptance Criteria}

All data from a properly functioning sensor will be considered valid for purposes of these checkout tests. The data will be visually inspected by the principal investigator or designee to determine proper sensor functionality prior to, or during each test sequence described in the objectives section of this test plan.

Table 2. Operating parameters and conversion factors for the digface characterization sensors.

\begin{tabular}{lllll}
\hline \multicolumn{1}{c}{ Sensor } & \multicolumn{1}{c}{$\begin{array}{c}\text { Manufacture and } \\
\text { Model }\end{array}$} & Operating Range & Output & Conversion factor \\
\hline Magnetometer & $\begin{array}{l}\text { Electro-Mechanical } \\
\text { Design Services, Inc., } \\
\end{array}$ & $\pm 330,000 \mathrm{nT} / \mathrm{m}$ & $\begin{array}{c}\text { Analog Output } \\
\pm 10 \mathrm{~V}\end{array}$ & $1 \mathrm{~V}=32808 \mathrm{nT} / \mathrm{m}$ \\
& $\begin{array}{l}\text { Model GRS-1 Single } \\
\text { Axis Fluxgate } \\
\text { Gradiometer }\end{array}$ & & & \\
& & & \\
\hline
\end{tabular}




\section{QUALITY ASSURANCE}

This effort will be performed in accordance with the requirements of quality Level 3 as defined in the EG\&G Quality Manual.

\subsection{General Quality Control Methods}

Quality control can be maintained by establishing that the experimental hardware is in proper working order prior to testing, and that sensors are responding properly during conduct of testing. Sensor response is addressed in Section 8 of this test plan describing data validation procedures. Correct hardware functionality can be ensured by performing a visual inspection of the sensor delivery system and DAS at the beginning and end of each day. This inspection will concentrate on abnormal wear on mechanical components and integrity of all electrical connections. Because the tests will occur in outdoor conditions, the general cleanliness of the equipment will be assessed and proper cleanup and preventative maintenance will be done. This may involve removing dust with compressed air equipment and lubrication of moving parts.

Should equipment malfunction or an abnormal operating condition occur, field operations will be suspended until the problem is resolved. If the problem is considered minor, field operation may continue at the discretion of the technical field leader(s).

\subsection{Specific Quality Control Procedures}

The digface characterization performance testing will adopt a set of specific quality control procedures that will govern all data acquisition. The quality control procedures for digface characterization performance testing are stated as follows.

Data collected during performance testing will be within the manufacturer recommended operating range for each sensor; data falling outside this range will be flagged immediately by the DAS or by field personnel.

Repeatability of all sensors will be monitored by duplicating data acquisition as discussed in the objectives section of this test plan. 


\section{EQUIPMENT AND INSTRUMENTS}

The equipment required for the digface characterization tests is provided from within the Digface Characterization Project. The major pieces involved with this test series are provided in Table 3.

Table 3. List of major DAS components.

\begin{tabular}{|c|c|c|}
\hline Equipment & Function & Comments \\
\hline $\begin{array}{l}\text { Sun workstation, } \\
\text { SPARC } 10 \text { class }\end{array}$ & $\begin{array}{l}\text { Display management and data } \\
\text { archival }\end{array}$ & $\begin{array}{l}\text { 1.5-GB disk storage, } 19 \text {-in. color } \\
\text { monitor, 32-Mb RAM }\end{array}$ \\
\hline PC microprocessor & $\begin{array}{l}\text { Remote sensor controller and } \\
\text { processor }\end{array}$ & $\begin{array}{l}\text { 33-Mhz } 80486 \text { DOS system, 4-MB } \\
\text { RAM, 2-MB solid state disk }\end{array}$ \\
\hline RF ethernet link & $\begin{array}{l}\text { Seamless transmission of data } \\
\text { from remote processor to Sun } \\
\text { workstation }\end{array}$ & $\begin{array}{l}1.6 \text { megabit per second sustained } \\
\text { data transfer rate }\end{array}$ \\
\hline A/D hardware & $\begin{array}{l}\text { Conversion of analog sensor } \\
\text { signals to digital representation }\end{array}$ & $\begin{array}{l}\text { 12-bit resolution with automatic gain } \\
\text { control }\end{array}$ \\
\hline $\begin{array}{l}\text { PV wave display } \\
\text { and analysis } \\
\text { software }\end{array}$ & $\begin{array}{l}\text { Commercial software display } \\
\text { management and analysis } \\
\text { functions }\end{array}$ & $\begin{array}{l}\text { Industry standard product. Portable } \\
\text { to a variety of workstation class } \\
\text { machines. }\end{array}$ \\
\hline Magnetometer & $\begin{array}{l}\text { Measurement of Earth's } \\
\text { magnetic field }\end{array}$ & $\begin{array}{l}\text { Electro-Mechanical Devices, Inc., } \\
\text { instrument model GRS-1 }\end{array}$ \\
\hline Laser range finder & $\begin{array}{l}\text { Provides topographical mapping } \\
\text { of the digface }\end{array}$ & $\begin{array}{l}\text { High resolution range finder using a } \\
670-\mathrm{nm} \text { visible ruby laser }\end{array}$ \\
\hline Color printer & Hardcopy of data analysis plots & $\begin{array}{l}\text { 300-dpi color ink jet printer with } \\
\text { PostScript and TCP/IP capability }\end{array}$ \\
\hline
\end{tabular}




\section{SUPPLIES, UTILITIES, AND FACILITIES}

Implementation of this test plan hinges upon the availability and support of personnel associated with the CTR project and the availability of the outdoor overhead gantry crane located behind the North Boulevard Annex in Idaho Falls. Onsite requirements include the availability of 120 -Vac power and a secure enclosure for housing the data acquisition equipment. 


\section{HEALTH AND SAFETY}

The ruby 670 -nm laser used to map the digface surface can present a blinding hazard under some circumstances. Operating procedures for the laser rangefinder will be reviewed and modified as required by contractor safety personnel. No special health and safety issues apply to this test activity. However, specialized training may be required by the operating procedures of the CTR program for the gantry crane. These are assumed to be outlined in the test plan for the CTR November demonstration test plan. The standard gatehouse and hazards communication training are required for all personnel on this project. 


\section{RESIDUALS MANAGEMENT}

No hazardous wastes or residuals will be generated as a result of this activity. 


\section{REFERENCES}

1. R. A. Hyde and K. M. Croft, Cooperative Telerobotic Retrieval Test Plan for Fiscal Year 1994, INEL-94/0035, Lockheed Idaho Technologies Company, Idaho Falls, 1994.

2. EG\&G Quality Manual (see Section 9), EG\&G Idaho, Inc., Idaho Falls, Idaho.

3. K. M. Croft, R. A. Hyde, and S. M. Allen, Digface Characterization Test Plan-Remote Testing, EGG-WTD-10771, 1993.

4. EG\&G Applied Geosciences Unit, Geosciences Standard Operating Procedures Manual, EG\&G Idaho, Inc., 1992.

5. N. E. Josten, Preliminary Design for a Safe Step Remediation System, EGG-EELS-002, 1992.

6. J. L. Morrison, BWID Core System Requirements and Test Objectives, draft letter JLM-01-93 to BWID, EG\&G Idaho, Inc., 1993.

7. L. C. Rounds and J. K. McDonald, Buried Waste Integrated Demonstration Technology Test Plan, EGG-WTD-9800, Rev. 1, January 1994. 
Appendix A

Sensor Technical Specifications 


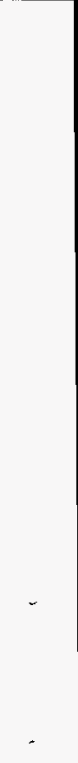




\section{Appendix A}

\section{Sensor Technical Specifications}

Table A-1. Single axis fluxgate gradiometer instrument specifications.

\begin{tabular}{|c|c|}
\hline Alignment error: & $\leq 0.05$ degrees \\
\hline Susceptibility to perming: & $\leq \pm 5 \mathrm{nT} / \pm 5$ Gauss \\
\hline Input voltage: & $\pm 15 \mathrm{Vdc}$ \\
\hline Input current: & $\begin{array}{l}\leq 40 \text { milliamps }(+15 \mathrm{Vdc}) \\
\leq 15 \text { milliamps }(-15 \mathrm{Vdc})\end{array}$ \\
\hline Magnetometer range: & $\pm 2,000$ milligauss $(200,000 \mathrm{nT})$ \\
\hline Gradiometer range: & \pm 333 milligauss $(33,330 \mathrm{nT})$ \\
\hline Accuracy: & $\leq \pm 0.1 \%$ of full scale \\
\hline Linearity: & $\leq \pm 0.02 \%$ of full scale \\
\hline Magnetometer sensitivity: & \pm 5.00 volts/gauss \\
\hline Gradiometer sensitivity: & \pm 30.00 volts/gauss \\
\hline Scale factor temperature shift: & $\leq 50 \mathrm{ppm} /{ }^{\circ} \mathrm{C}$ \\
\hline Noise: & $\begin{array}{l}\leq 35 \text { picotesla } \mathrm{RMS} / \sqrt{\mathrm{Hz}} \text { at } 1 \mathrm{~Hz} \\
\leq 15 \text { picotesla } \mathrm{RMS} / \sqrt{\mathrm{Hz}} \text { at } 1 \mathrm{~Hz}\end{array}$ \\
\hline Output ripple: & $\leq 5$ millivolt peak to peak @2nd harmonic \\
\hline Analog output@zero field: & $\leq \pm 3.0$ millivolt \\
\hline Zero shift with temperature: & $\leq 0.15$ nanotesla ${ }^{\circ} \mathrm{C}$ \\
\hline Output impedance: & $100 \mathrm{ohm} \leq 5 \%$ \\
\hline Frequency response: & $-3 \mathrm{~dB} @>100 \mathrm{~Hz}$ \\
\hline Weight: & $\leq 0.82 \mathrm{Kg}$ (both sensors) \\
\hline Cable length: & $\begin{array}{l}\text { Electronic case } 16.5 \times 5.1 \times 5.3 \mathrm{~cm} \\
\text { Sensor case } 15.25 \times 3.15 \times 4.4 \mathrm{~cm}\end{array}$ \\
\hline
\end{tabular}




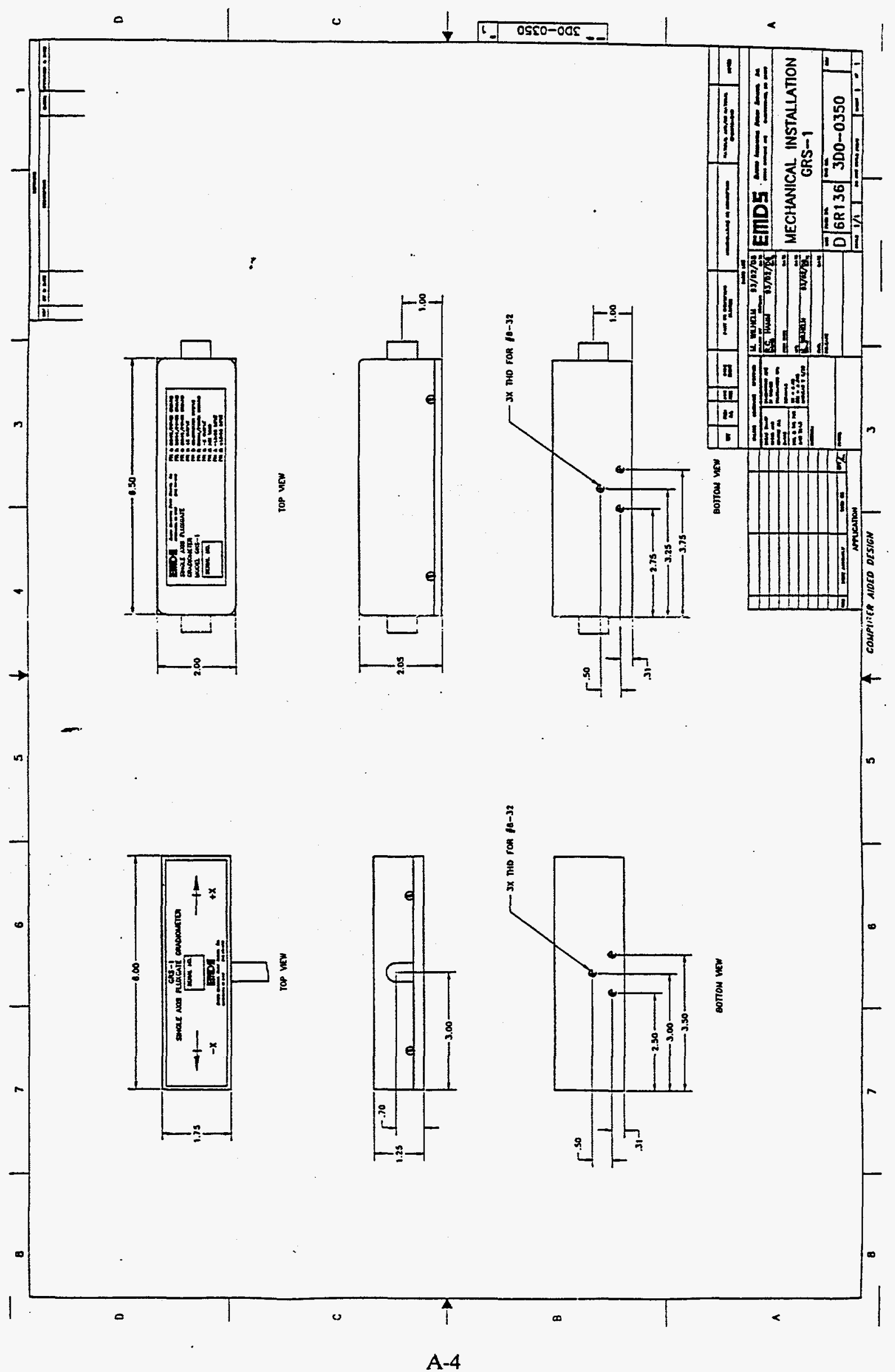




\section{Appendix B}

DAS Drawings and Schematics 



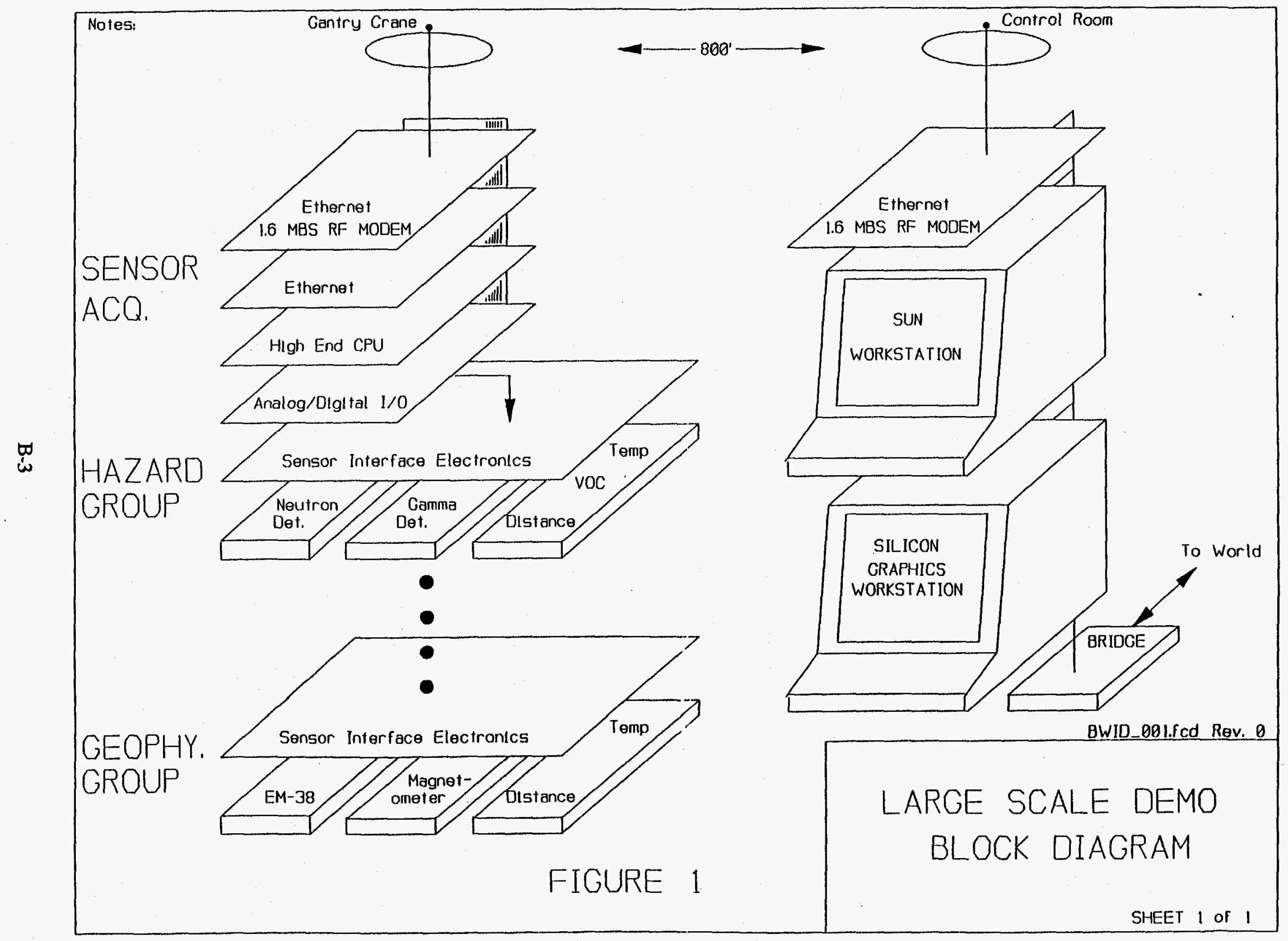




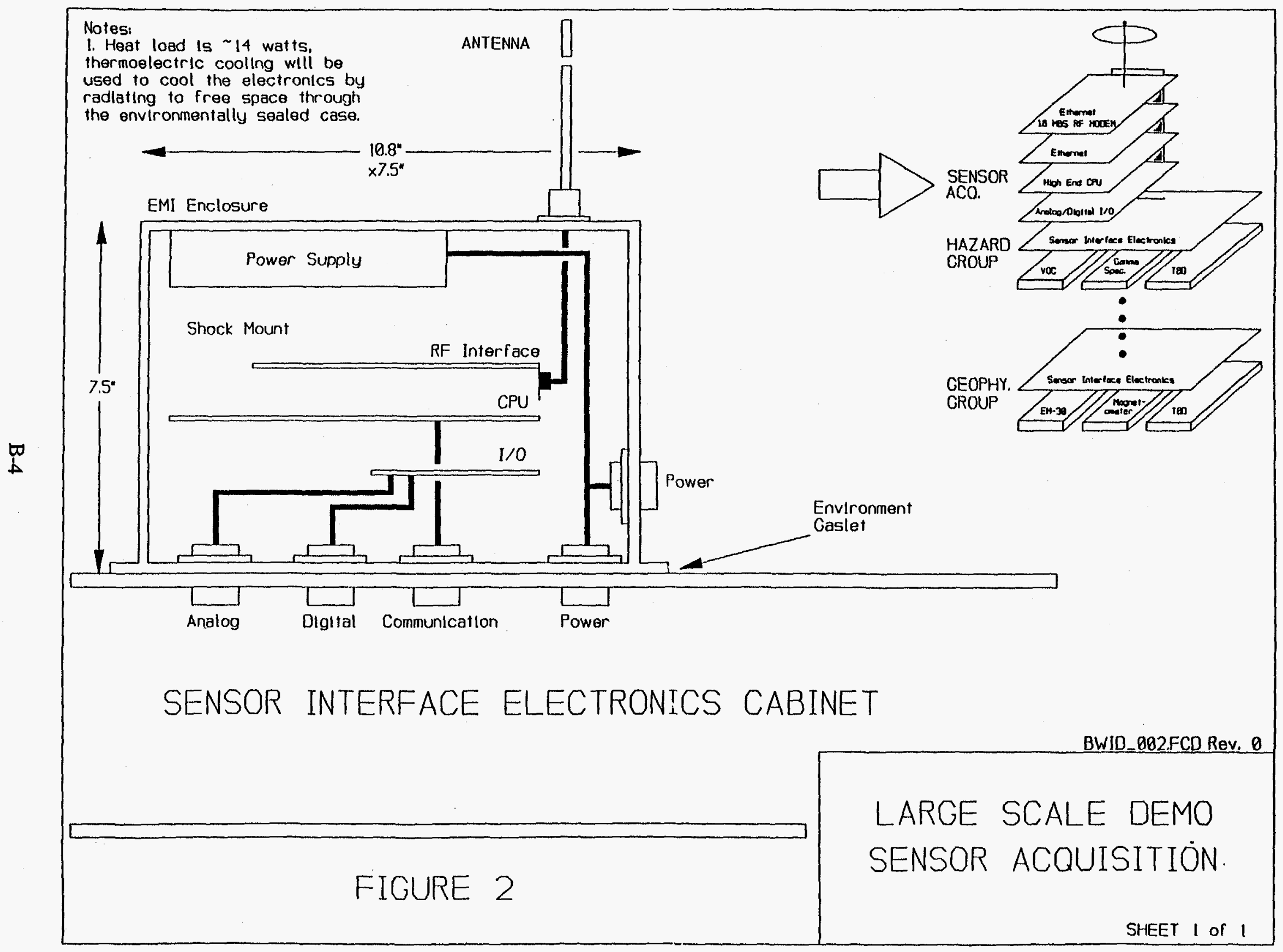




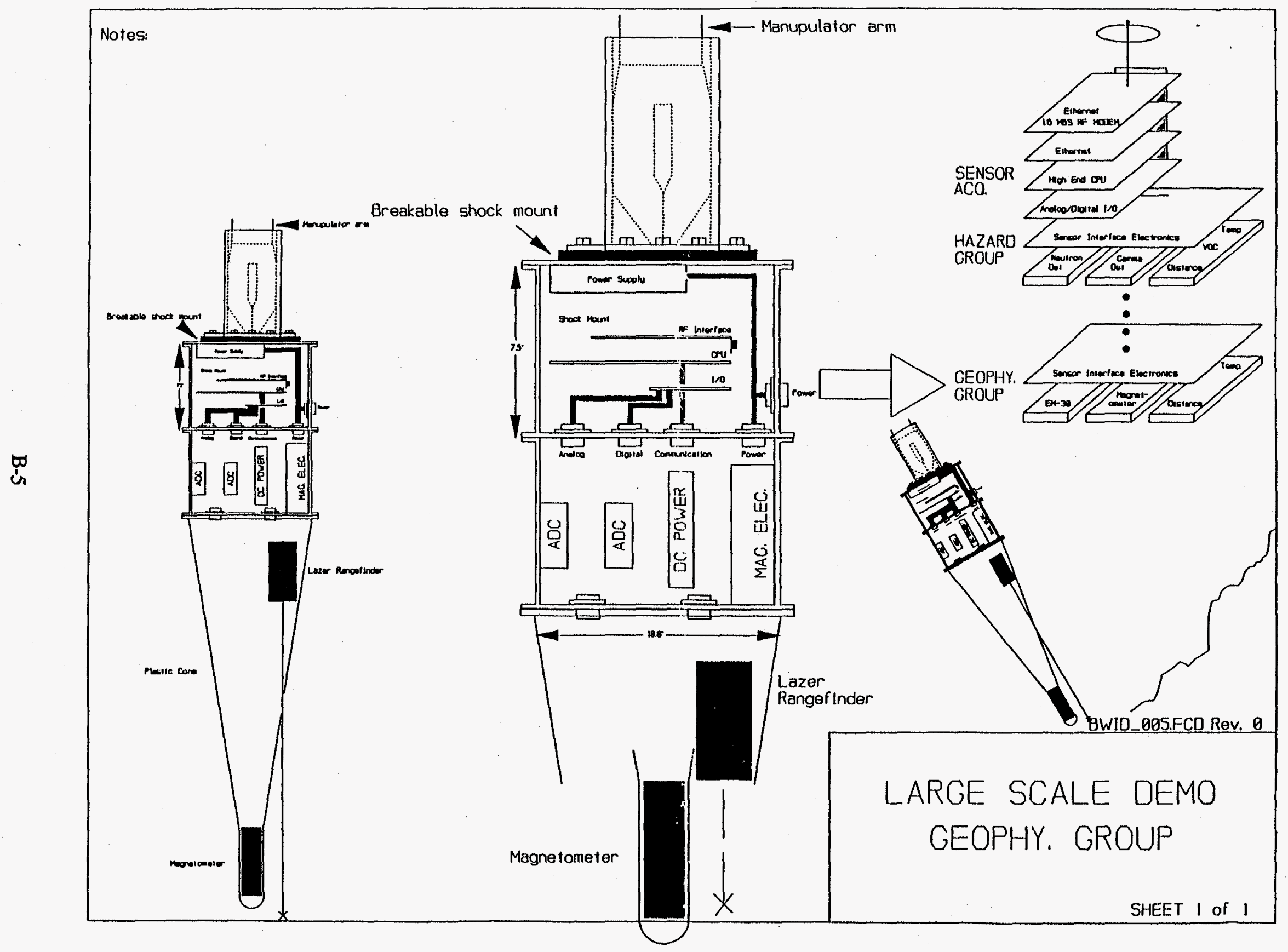




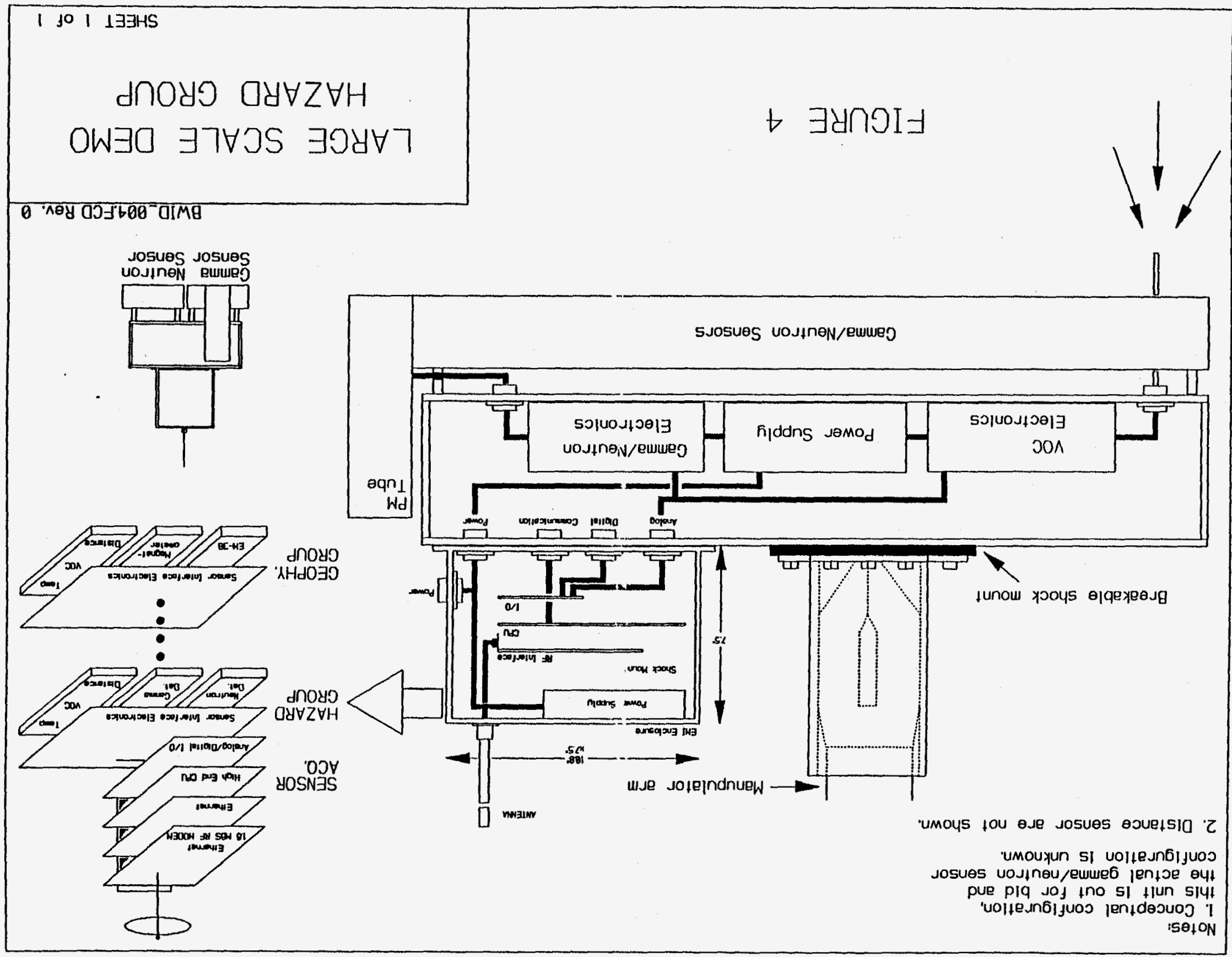




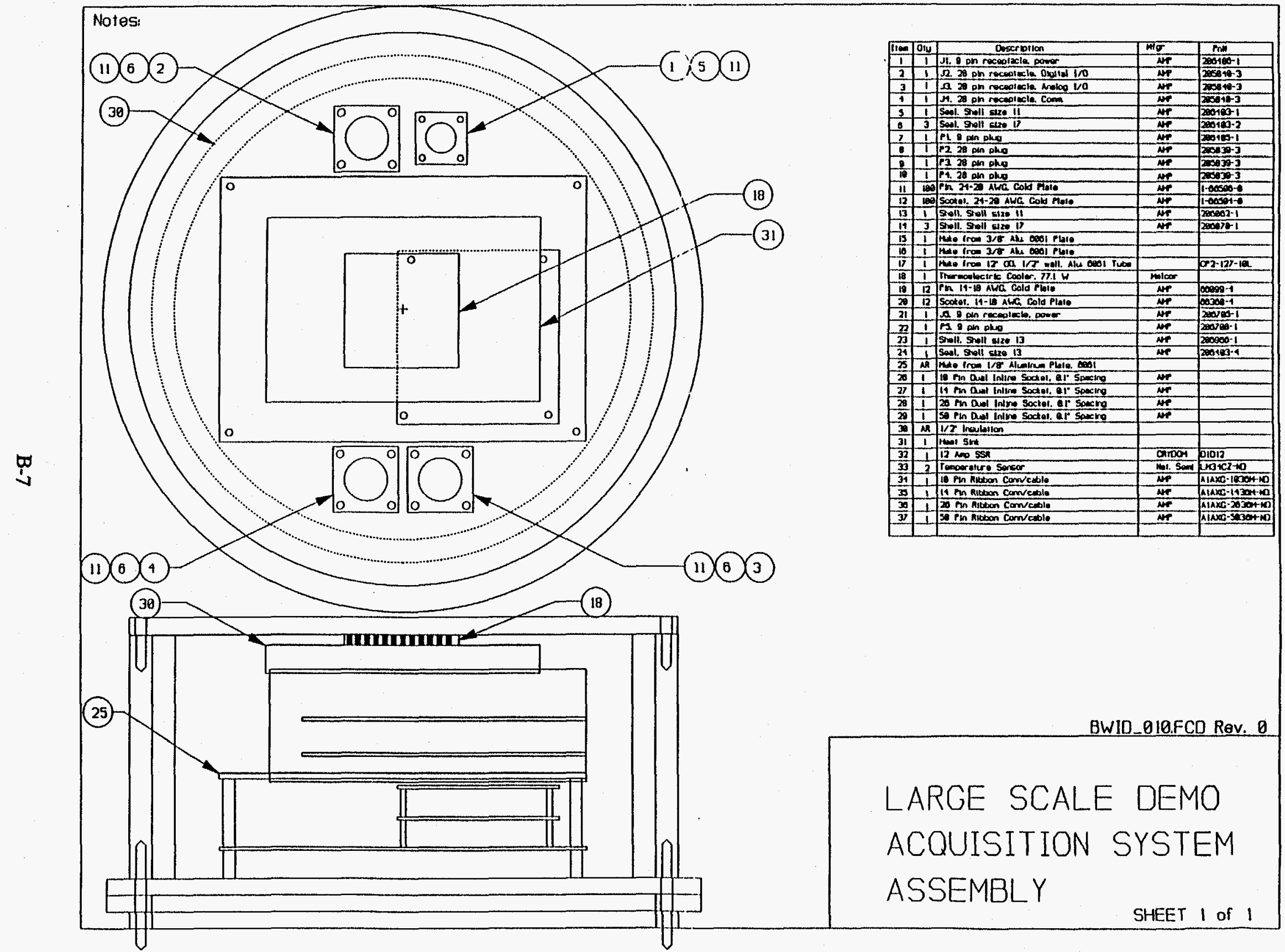




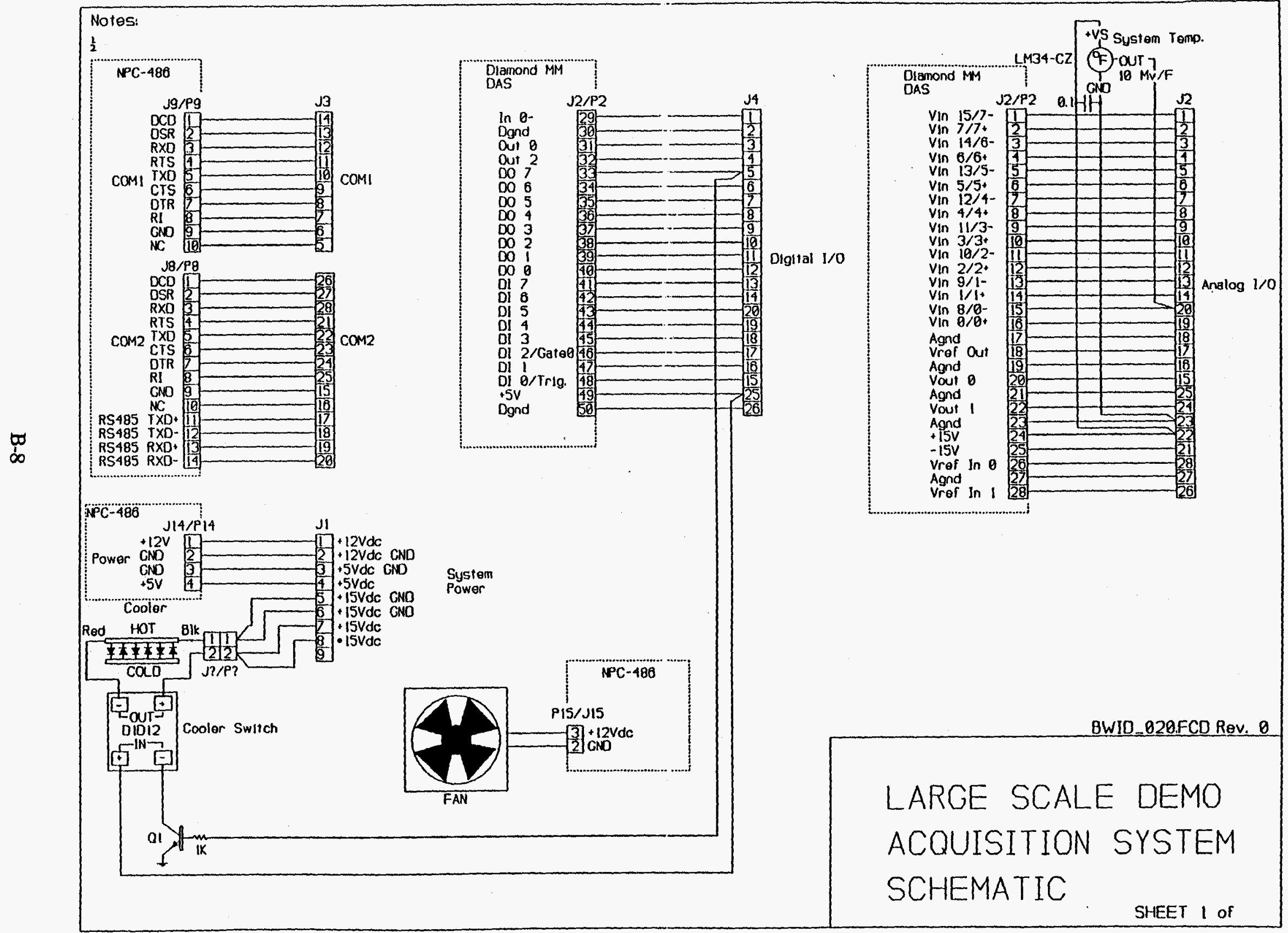




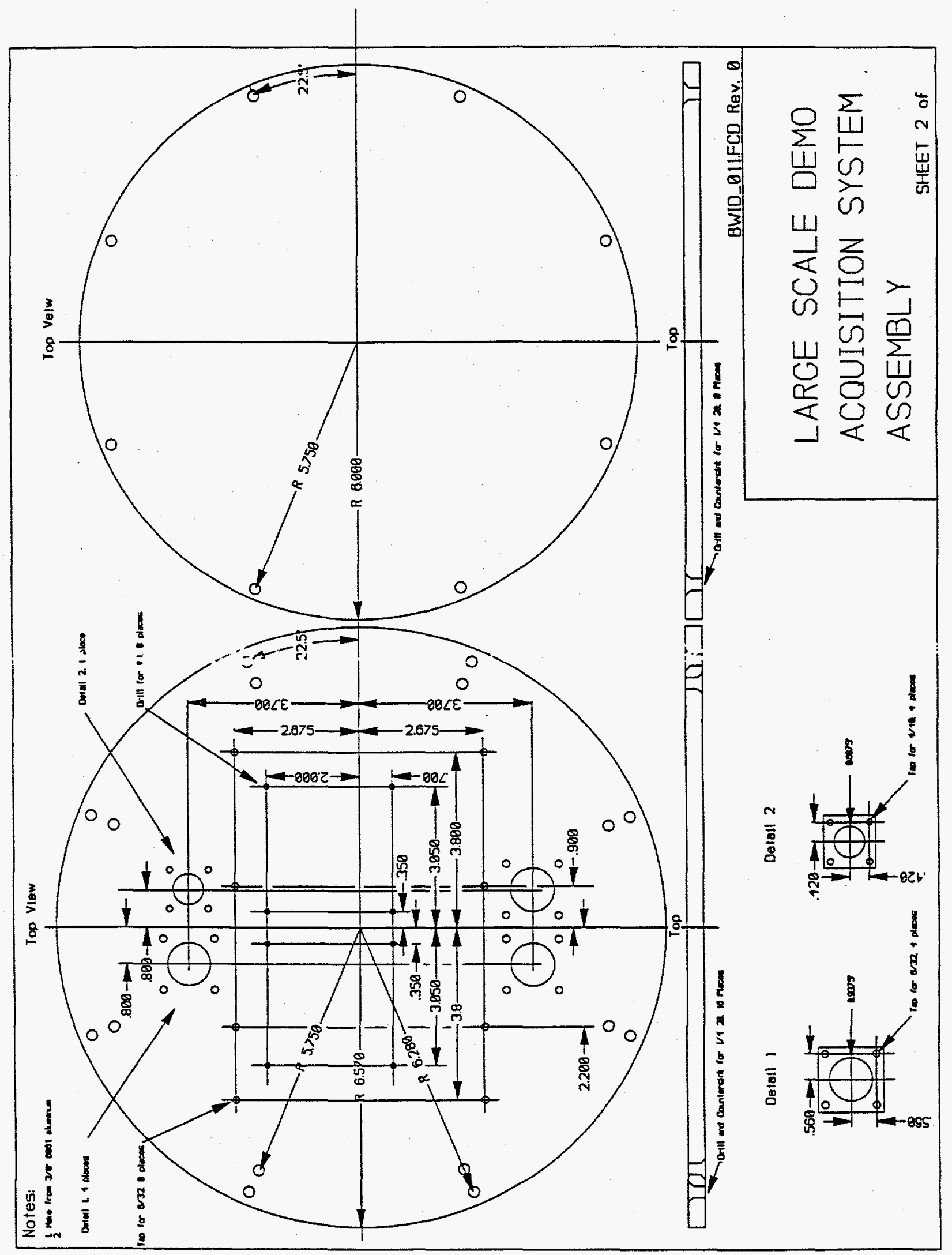




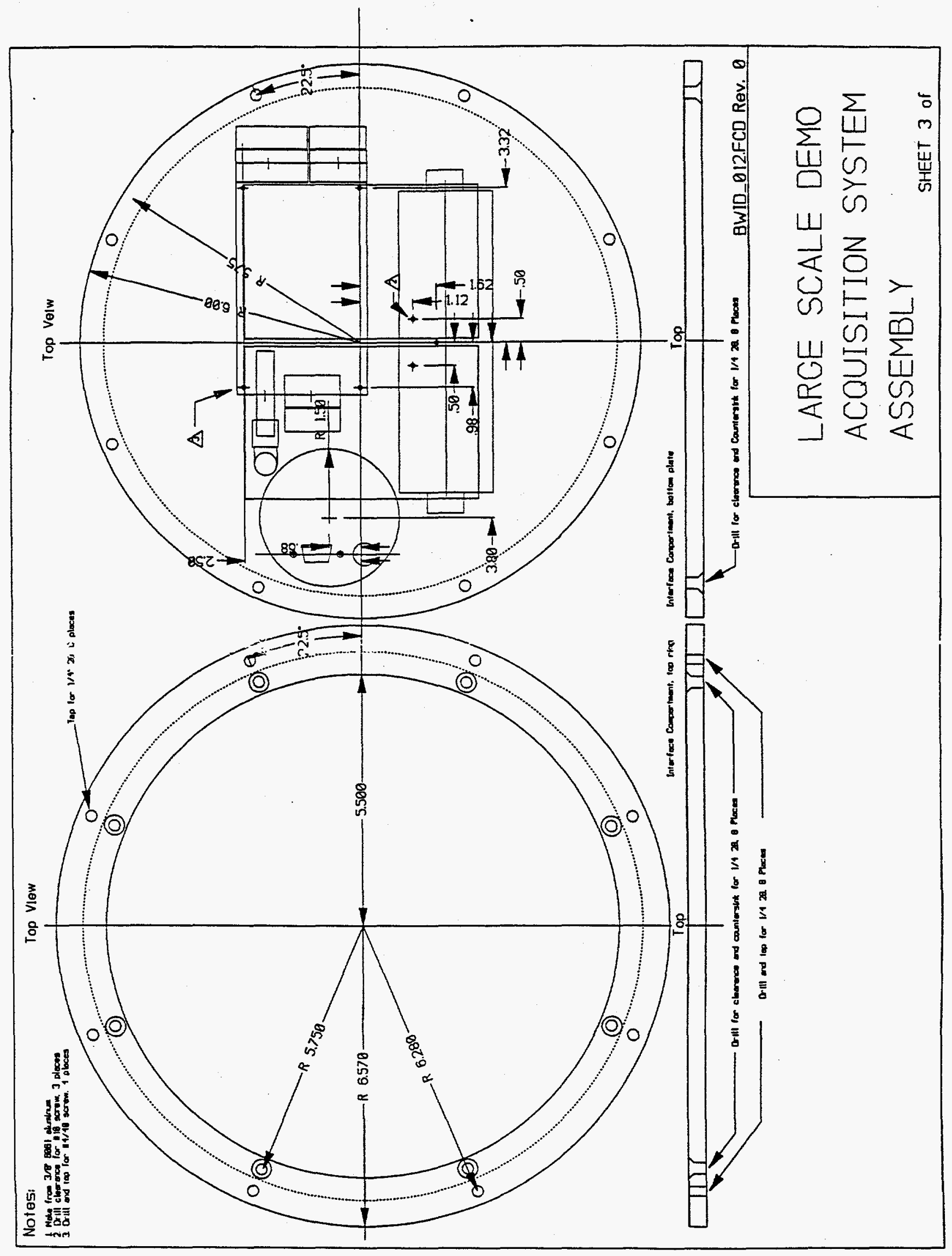




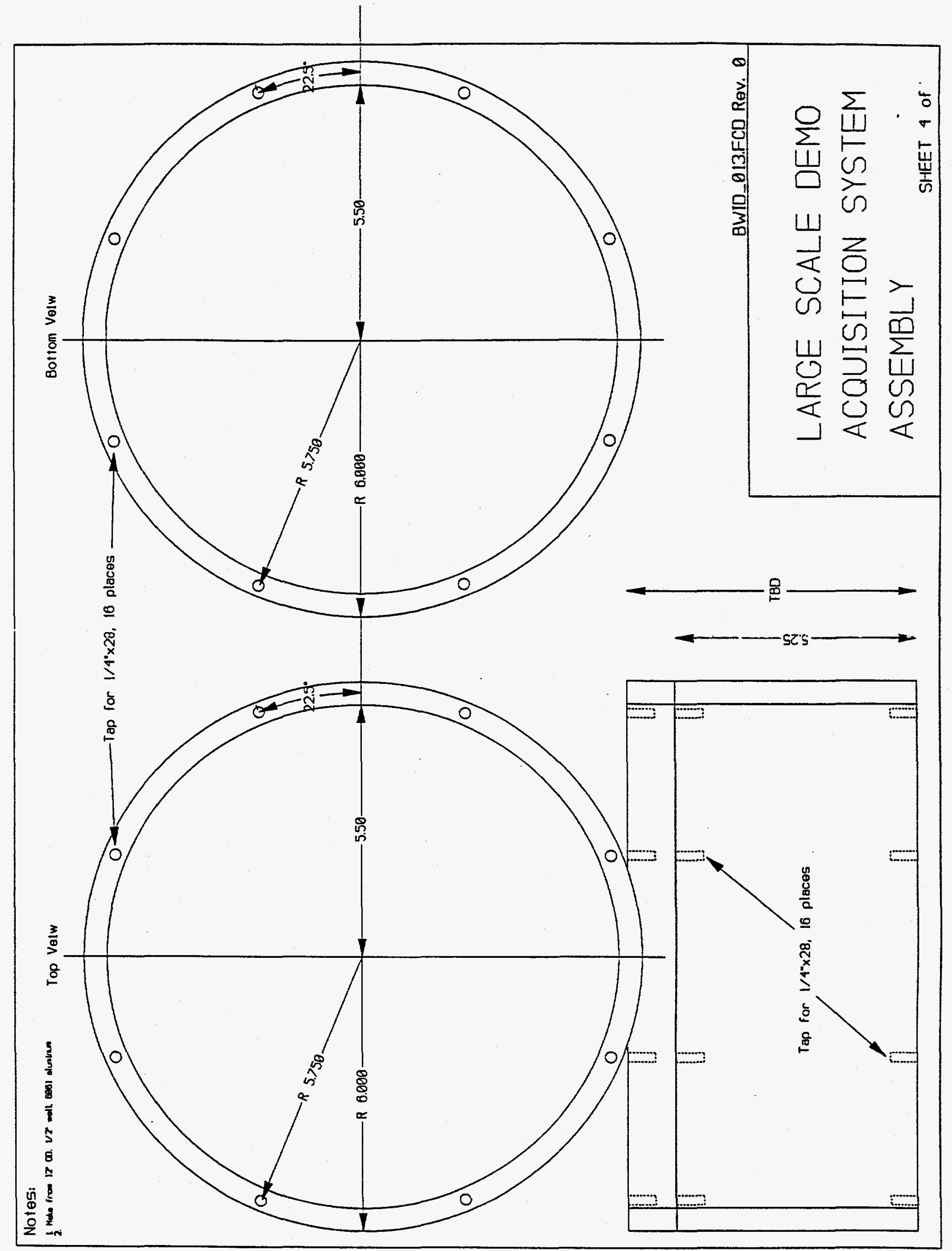

B-11 